\title{
STICKY PLASTIC SHEET TRAPS AS SURVEY TOOLS FOR THE EUROPEAN CHAFER (COLEOPTERA: SCARABAEIDAE)'
}

\author{
B. J. FIORI
}

Northeast Regional Plant Introduction Station, Agricultural Research Service, United States Department of Agriculture, New York State Agricultural Experiment Station, Geneva, New York 14456

\begin{abstract}
Can. Ent. 115: 1429-1431 (1983)

A perforated $4.6 \mathrm{~m}$ square sticky plastic sheet placed under the canopy of a tree heavily populated with European chafers, Rhizotrogus majalis (Razoumowsky), consistently captured more beetles than a 15 -w blacklight survey trap. The same size sheet, operating with a bird shield under a sparsely populated tree that represented conditions encountered during survey operations, demonstrated detection capability equal to that of the light trap. Bird shields prevented trapping of birds. Lawn injury beneath the sheeting due to heat build-up was not serious. Results suggest that a sticky sheet is an alternative, less expensive, equally effective survey tool for detection of European chafer infestations.
\end{abstract}

\section{Résumé}

Une feuille de plastique perforée et engluée de $4.6 \mathrm{~m}^{2}$ placée sous le couvert d'un arbre fortement infesté du hanneton européen, Rhizotrogus majalis (Razoumowsky), a permis de capturer systématiquement plus de coléoptères qu'un piège lumineux à inventaire de type "blacklight" de $15 \mathrm{w}$. Une feuille de mêmes dimensions placée sous un abri à oiseaux en dessous d'un arbre peu infesté, représentant les conditions opérationnelles de dépistage, a montré un pouvoir de détection égal à celui du piège lumineux. L'abri à oiseaux prévient la capture d'oiseaux. Le brûlage de l'herbe dû à l'accumulation de la chaleur sous les feuilles de plastique n'est pas sérieux. Ces résultats permettent de croire que la feuille engluée est une technique alternative moins dispendieuse et tout aussi efficace pour le dépistage des infestations du hanneton européen.

Baffled 15-w blacklight traps operated under canopies of trees to which beetles fly are effective survey tools that had limited use by U.S.A. federal and state agencies for detection of incipient infestations of the European chafer, Rhizotrogus majalis (Razoumowsky) (Tashiro et al. 1967). When survey areas are distant from electrical utility, extensive wiring is necessary and in some situations overhead wiring must be installed. Alternatively, an inverter, photocell, and electric storage battery are required for each trap or a field generator is required for each survey area.

Fiori et al. (1973) demonstrated that sticky plastic placed under the entire canopy of a flight tree captured 4.4 times more chafers than a 30 -w blacklight trap. Behavior studies (Fiori 1976) suggest that the chafer's habit of tumbling down from flight trees is not a response to light traps, but rather they are attracted to blacklight after tumbling down. Because sticky sheets operate without electricity, we decided to test the effectiveness of various size sticky sheets and compare their capturing efficiency with that of blacklight traps.

\section{Materials and Methods}

During the 1973 flight season 15-w blacklight traps or sheets of 6-mil thick, translucent, perforated, sticky, polyethylene plastic were placed under each of four maple trees in Newark, New York. Trees were symmetrical, $6 \mathrm{~m}$ tall, with $4.9 \mathrm{~m}$ diam. canopies, and were situated $15.2 \mathrm{~m}$ apart surrounded by a well-maintained lawn.

Sheets were perforated for ventilation with $3.2 \mathrm{~mm}$ diam. holes $10.2 \mathrm{~cm}$ apart, slitting from outer edges to $12.7 \mathrm{~cm}$ diam. holes in the center and fitted around the tree trunks. In place, edges of the slit were overlapped slightly and held together with Tack Trap ${ }^{\circledR}$. Edges of the sheet were held down with $5 \mathrm{~cm}$ square $\times 2.2 \mathrm{~m}$ wood strips. Tack Trap

\footnotetext{
${ }^{1}$ Mention of any commercial product does not constitute endorsement by the United States Department of Agriculture.
} 
(diluted 1:1 with gasoline to facilitate application and distribution) was applied to the surface with a hand-pressurized sprayer at the rate of $0.41 \mathrm{~L} / \mathrm{m}^{2}$.

Light traps were hung from $1.8 \mathrm{~m}$ long steel rods and were positioned $0.6 \mathrm{~m}$ from the east side of the trunk; lamps were powered with a gasoline engine-driven alternator.

A $1.5 \mathrm{~m}$ square sheet was alternated nightly with a light trap under tree $1 ; 3.1,4.6$, and $6.1 \mathrm{~m}$ square sheets were alternated nightly with a light trap under trees 2,3 , and 4 . When not in use, sheets were folded so that sticky surfaces were not exposed, then folded or rolled and stored at the test site. The test was conducted for 10 consecutive nights beginning 15 June so there were 5 alternate night comparisons of chafer capture between each size sheet and a light trap. Sheets and light traps were operated from $2030 \mathrm{~h}$ EDT (about $15 \mathrm{~min}$ before the beginning of chafer flights) to $0600 \mathrm{~h}$ when all adult chafer aboveground activity had ceased.

Because people were present at the site in the early morning, bird trapping (Fiori et al. 1973) was not a problem and bird shields were not used. Also, removal of the sheets each morning prevented possible injury to the lawn. Therefore, after the last night of the trapping test, the $4.6 \mathrm{~m}$ square sheet was left in place for 8 consecutive days and nights to determine if lawn injury would occur. A bird shield constructed of $6.3 \mathrm{~cm}$ mesh poultry wire was placed over the sheet and held about $29 \mathrm{~cm}$ above it with wooden stakes, but was bent down to contact the lawn along the edges of the sheet.

During the 1974 flight season a standard 15-w light survey trap and a $4.6 \mathrm{~m}$ square, perforated sticky sheet were operated on alternate nights under a $9.1 \mathrm{~m}$ tall linden tree with a $12.2 \mathrm{~m}$ diam. canopy in Phelps, New York. This size sheet was chosen because it was the smallest size that consistently captured more chafers in 1973 . The location was not heavily infested and the test began towards the end of the flight season ( $8 \mathrm{July}$ ) when few chafers were flying to the tree. Such sparse flights are typical of the conditions encountered when surveys take place. The sheet was prepared as described except it was not necessary to cut the sheet to accommodate the tree trunk. The area beneath the canopy was large enough so that the sheet did not extend out beyond the canopy.

Traps were attended and chafer captures recorded at $0830 \mathrm{~h}$. Traps were operated for 18 consecutive nights, giving 9 alternate night comparisons of chafer capture. Each evening during the flight period (approx. $2045 \mathrm{~h}$ to $2115 \mathrm{~h}$ ) chafers seen flying to the tree were counted. Counts and captures of both devices were compared.

\section{Results and Discussion}

In 1973 the $1.5 \mathrm{~m}$ square sheet consistently captured fewer chafers than the light trap; the $3.1 \mathrm{~m}$ square sheet captured more total chafers than the light trap but the number was greater in only 2 of 5 comparisons. The 4.6 and $6.1 \mathrm{~m}$ square sheets consistently captured more than the light trap. Larger sheets captured progressively greater total numbers of chafers (Table I)

When the $4.6 \mathrm{~m}$ square sheet was removed, tips of grass that had pressed against the bottom of the sheet were burned. The damage was not considered serious because it was removed by a single mowing. No birds were trapped.

In 1974, the $4.6 \mathrm{~m}$ square sheet used as a survey tool captured a total of 43 chafers on nights when a total of 30 were seen; it captured more chafers during 2 of the 9 nights and fewer during 5 nights. On 2 nights it detected chafers when none were seen. The light trap captured a total of 26 chafers on nights when 24 were seen; it captured more chafers during 4 of 9 nights, fewer chafers during 3 nights, and an equal number during 2 nights. The sheet captured more chafers during 4 of the 9 alternate night comparisons with the light trap; it captured fewer chafers on 2 nights and an equal number on 3 nights. No birds were trapped. The three methods of survey appear equal in their ability to detect adult chafers under survey conditions. 
Table I. Captures of European chafers under similar flight trees, Newark, New York, 30 June to 10 July 1973

\begin{tabular}{|c|c|c|c|c|c|c|c|c|}
\hline \multirow[b]{2}{*}{ Night } & \multicolumn{4}{|c|}{$\begin{array}{l}\text { Captures on sticky sheets } \\
\text { under tree no. }\end{array}$} & \multicolumn{4}{|c|}{$\begin{array}{l}\text { Captures in } 15-w \text { blacklight traps } \\
\text { under tree no. }\end{array}$} \\
\hline & 1 & 2 & 3 & 4 & 1 & 2 & 3 & 4 \\
\hline 1 & 121 & & 510 & & & 163 & & 281 \\
\hline 2 & & 257 & & 604 & 209 & & 87 & \\
\hline 3 & 21 & & 288 & & & 142 & & 252 \\
\hline 4 & & 127 & & 353 & 67 & & 35 & \\
\hline 5 & 2 & & 30 & & & 8 & & 14 \\
\hline 6 & & 52 & & 130 & 25 & & 17 & \\
\hline $\begin{array}{l}7 \\
8\end{array}$ & 11 & & 60 & & & 42 & & 31 \\
\hline $\begin{array}{l}8 \\
9\end{array}$ & & 37 & & 57 & 44 & & 44 & \\
\hline $\begin{array}{r}9 \\
10\end{array}$ & 5 & & 40 & & & 23 & 6 & 29 \\
\hline & & & & Jo & 14 & & 0 & \\
\hline $\begin{array}{l}\text { Total } \\
\quad \text { captured }\end{array}$ & 160 & 485 & 928 & 1174 & 359 & 378 & 189 & 607 \\
\hline
\end{tabular}

aSheet sizes were: tree $1-1.5$; tree $2-3.1$; tree $3-4.6$; tree $4-6.1 \mathrm{~m}$ square. Sheets used without bird shields.

The expected consistently greater capture of the $4.56 \mathrm{~m}$ square sheet in comparison to the light trap (Table I) was not realized in 1974. Some chafers were observed clinging to the bird shield and some of these flew away. The bird shield certainly is necessary but it obviously diminished captures. Large mesh bird shields probably would intercept fewer chafers.

The advantages of the light trap (Tashiro et al. 1967) and the sticky sheet are that people need not be stationed at each flight tree and specimens are captured for positive identification. Advantages of the sticky sheets are that they can be constructed of simple and inexpensive materials and can be used with at least equal detection capability to survey areas remote from electrical utilities. Sticky sheets are inconvenient to use and require considerable time to install. Commercial preparation and folding of the sheets so that sticky surfaces are not exposed during transport and handling would avoid some inconvenience and reduce the time required for installation.

Recently, sticky sheets as well as observation, light traps and chemical lure traps were used in a rather extensive European chafer survey in southern Ontario. Sheets detected a new county record of infestation at Cainsville, Brant County (Reid 1980).

The nocturnal behavior of adult European chafers (Fiori 1976) and the relationship between sheet size and chafer capture (Table I) indicate that any device that will retain chafers after they fall, can serve as a survey tool with equal or greater detection capability (depending on size) than a blacklight trap. Findings provide a basis for further development of survey devices. Possibly, collapsible, funnel-shaped traps of polyethylene sheeting provided with a receptacle could be constructed for placement beneath flight trees. Such a design would eliminate the need for a sticky substance, the most troublesome component of sticky sheets and for bird shields, a probable deterrent against efficiency.

\section{Acknowledgment}

I thank Mr. W. T. Arehart, Agricultural Research Technician, USDA, ARS for his assistance in conducting the tests.

\section{References}

Fiori, B. J. 1976. European chafer: aspects of night behavior. J. econ. Ent. 69: 462-464.

Fiori, B. J., G. A. Fryer, and M. McKoy. 1973. Trapping European chafers: sticky plastic sheeting vs, blacklight trap. J. econ. Ent. 66: 1225-1226.

Reid, W. 1980. European chafer report for 1980. Agriculture Canada, Plant Products and Quarantine Division. 5 pp.

Tashiro, H., J. G. Hartsock, and G. G. Rowher. 1967. Development of blacklight traps for European chafer surveys. Tech. Bull. U.S. Dep. Agric. $1366.52 \mathrm{pp}$.

(Received 30 November 1982; accepted 10 March 1983) 